\title{
LDL Level in Ischaemic Stroke Patients at Dr. Soetomo General Hospital Surabaya
}

\author{
Mayori Rachmawati ${ }^{1}$, Rr. Indrayuni Lukitra Wardhani², Paulus Sugianto ${ }^{3 *}$ \\ ${ }^{1}$ Faculty of Medicine Universitas Airlangga, Surabaya, Indonesia \\ ${ }^{2}$ Department of Physical and Rehabilitation Medicine, Faculty of Medicine Universitas Airlangga, Surabaya, Indonesia - Dr. \\ Soetomo General Hospital Surabaya, Indonesia \\ ${ }^{2}$ Department of Neurology, Faculty of Medicine Universitas Airlangga, Surabaya, Indonesia - Dr. Soetomo General Hospital \\ Surabaya, Indonesia
}

\section{A R T I C L E I N F O}

\section{Article history:}

Received 11 May 2019

Received in revised form 27 May 2019

Accepted 24 June 2019

Available online 30 June 2019

\section{Keywords:}

Ischemic stroke,

Total Cholesterol,

Low Density Lipoprotein,

High Density Lipoprotein,

Tryglicerides.

\section{*) Corresponding author:}

paulus.sugianto@gmail.com

\begin{abstract}
A B S T R A C T
Introduction: Stroke is one of the top killers amongst the non-infectious diseases. Ischemic stroke dominates the rate by $87.0 \%$ amongst all type of strokes. One of the risk factors for stroke ischemic stroke is atherosclerosis which caused by lipid build-up in the arteries.

Methods: This research is a retrospective study on secondary data. Admitted Ischaemic stroke patients. Lipid profile, and Barthel Index were collected from medical record and presented descriptively.

Results: Of the 248 patients, 144 (58.1\%) were men, mean age was 59.33. 61.7\% ischemic stroke patients have their LDL level elevated, 59.7\% HDL decreased, 39.1\% total cholesterol elevated, and $33.9 \%$ TG elevated. This study also observe the dependency based on Barthel Index of the admitted stroke patients. $75 \%$ percents amongst subjects were categorized as "total dependece" are having their LDL level elevated.

Conclusion: Most of stroke patients have elevated LDL and HDL while the TG and total cholesterol are mostly optimized. Stroke patients whose admitted with "total dependence" most likely to have elevated LDL in this study.
\end{abstract}

\section{Introduction}

Amongst the non-infectious diseases in the world, stroke is the second common cause of deaths of longterm disability with high incidence rate and deaths $(21.2 \%)$ which percentage is higher than ischemic heart disease $(8.9 \%)$ and diabetes mellitus $(6.5 \%){ }^{1}$

Based on trends of global burden data from 1990 - 2013, adults aged 20 to 64 years, the global prevalence of ischemic stroke was 7.3 million cases, with men having consistently greater incidence of ischemic stroke than women $\left(133 / 100.000\right.$ and 99/100,000, respectively. ${ }^{2,3}$

There are two types of major stroke, ischaemic and haemorrhagic. Ischaemic stroke leads with $87.0 \%$ amongst all strokes. ${ }^{4}$ Stroke is a clinical manifest of brain dysfunction (local or global) occurs when there are problems at brain's vessels such as something clogs blood supply to part of the brain (ischemic stroke) or when a blood vessel in the brain ruptures (hemorrhagic stroke). ${ }^{4}$ Regarding to American Heart Association, Ischemic stroke is an infarct in central nervous system (brain, vertebral spine, and retinal ganglion cells) which manifest with visible symptoms so that it will differentiate from silent stroke. ${ }^{5}$ Risk factors for strokes are divided into modifiable and non-modifiable. Age, sex, genetics, and race are non-modifiable risk factors. ${ }^{6}$ Smoking, alcohol abuse, do no exercise, having history of diseases such as stroke, diabetes, dyslipidemia, hypertension, and other cardiovascular diseases are examples of modifiable risk factors. ${ }^{7}$

There are three major etiology in ischemic stroke which is cardioembolic, vasculopathy, and atherosclerosis..$^{8,9}$ Atherosclerosis is generally caused by LDL accumulation inside vascular endothelial. ${ }^{1,10,11}$ Saposnik et al (2014) found that more than $45 \%$ patients with recurrent stroke attacks are presented with high LDL level $(>100 \mathrm{mg} / \mathrm{dL}) .{ }^{12}$ Thus, measuring lipid profile in ischemic stroke patients could be useful to help diagnostic and therapy. We conducted this study to know LDL level is presented and impact in ischemic stroke patients at Dr. Soetomo General Hospital.

\section{Methods}

This study was conducted at Dr. Soetomo General Hospital (Surabaya) from January to March 2018. This research had been approved by research committee of Dr. Soetomo General Hospital (0113/KEPK/III/2018). All admitted Ischemic stroke patients within inclusion criteria: had complete record and lipid profile. The 
exclusion criteria were any data which was incomplete or data couldn't be read clearly. Age, sex, admission date, lipid profile, and Barthel Index were collected from medical record. The lipid profile which was used to conduct this research was the lipid profile measured when firstly admitted to Dr. Soetomo General Hospital Surabaya. Descriptive data was presented with tables. Barthel index is also used as an additional data to describe the outcome of stroke patients.

\section{Results}

From 309 stroke patients whom admitted from January to March 2018, 248 was included into the criteria. 144 patients $(58.1 \%)$ were men with men to women ratio was 1.38:1 and average age was 59.61 (SD 13.162). The most common group was $55-64$ years old. Those range of age was still productive age.

From table 2 we can see that in this study patients with not optimized LDL level was more common (71.9\%). Patients with desirable level of HDL was lower than half of the total patients $(40.3 \%)$. The percentage of patients with normal triglycerides level and normal total cholesterol level were dominant.

Stroke patients' disability was measured by Barthel index. Table 3 explained that patients with total dependency and not optimized LDL level were $75 \%$, patients with severe dependency and not optimized LDL level were $58.3 \%$, patients with moderate dependency and not optimized LDL level were $75 \%$. Patients with low Barthel index score (slight dependent and independent) were only $10 \%$ of all patients whom Barthel index score were recorded.

Table 1. Age and Sex distribution of Dr. Soetomo General Hospital Ischemic Stroke Patients

\begin{tabular}{cccc}
\hline Age & Men & Women & Total \\
\hline $\begin{array}{c}\text { Age (10 } \\
\text { years } \\
\text { group) }\end{array}$ & & & \\
\hline$<15$ & 1 & 0 & 1 \\
\hline $15-24$ & 1 & 1 & 2 \\
\hline $25-34$ & 5 & 1 & 6 \\
\hline $35-44$ & 9 & 8 & 17 \\
\hline $45-54$ & 31 & 19 & 50 \\
\hline $55-64$ & 53 & 39 & 92 \\
\hline $65-74$ & 29 & 27 & 56 \\
\hline $75-84$ & 11 & 7 & 18 \\
\hline $85-94$ & 2 & 2 & 4 \\
\hline$>95$ & 2 & 0 & 2 \\
\hline Total & 144 & 104 & 248 \\
\hline
\end{tabular}

Table 2 Distributions of Dr. Soetomo General Hospital Ischemic Stroke Patients Based on Their Lipid Profile

\begin{tabular}{|c|c|c|c|}
\hline Lipid & Profile & Frequencies & $\%$ \\
\hline \multirow{6}{*}{$\begin{array}{l}\text { Low Density } \\
\text { Lipoprotein }\end{array}$} & $\begin{array}{l}\text { Optimal } \\
(<100 \mathrm{mg} / \mathrm{dl})\end{array}$ & 70 & 28.1 \\
\hline & $\begin{array}{l}\text { Near Optimal } \\
(100-129 \mathrm{mg} / \\
\text { dl) }\end{array}$ & 77 & 31.0 \\
\hline & Borderline & 61 & 24.6 \\
\hline & $\begin{array}{l}\text { High (130- } \\
159 \mathrm{mg} / \mathrm{dl})\end{array}$ & & $\%$ \\
\hline & $\begin{array}{l}\text { High }(160- \\
189 \mathrm{mg} / \mathrm{dl})\end{array}$ & 30 & 12.1 \\
\hline & $\begin{array}{l}\text { Very High } \\
(\geq 190 \mathrm{mg} / \mathrm{dl})\end{array}$ & 10 & \\
\hline \multirow{2}{*}{$\begin{array}{l}\text { High Density } \\
\text { Lipoprotein }\end{array}$} & $\begin{array}{l}\text { Low }(<40 \\
\mathrm{mg} / \mathrm{dl})\end{array}$ & 130 & 59.7 \\
\hline & $\begin{array}{l}\text { Desirable (> } \\
40 \mathrm{mg} / \mathrm{dl})\end{array}$ & 118 & 40.3 \\
\hline \multirow{4}{*}{ Triglycerides } & $\begin{array}{l}\text { Normal }(< \\
150 \mathrm{mg} / \mathrm{dl}) \\
\end{array}$ & 164 & 66.1 \\
\hline & $\begin{array}{l}\text { Borderline } \\
\text { high (150-199 } \\
\mathrm{mg} / \mathrm{dl})\end{array}$ & 37 & 14.9 \\
\hline & $\begin{array}{l}\text { High (200- } \\
499 \mathrm{mg} / \mathrm{dl})\end{array}$ & 46 & 18.5 \\
\hline & $\begin{array}{l}\text { Very high } \\
(>500 \mathrm{mg} / \mathrm{dl})\end{array}$ & 1 & 0.4 \\
\hline \multirow{3}{*}{$\begin{array}{l}\text { Total } \\
\text { Cholesterol }\end{array}$} & $\begin{array}{l}\text { Desirable } \\
(<200 \mathrm{mg} / \mathrm{dl})\end{array}$ & 151 & 60.9 \\
\hline & $\begin{array}{l}\text { Borderline } \\
\text { High (200- } \\
239 \mathrm{mg} / \mathrm{dl})\end{array}$ & 61 & 24.6 \\
\hline & $\begin{array}{l}\text { High }(240 \mathrm{mg} / \\
\text { dl) }\end{array}$ & 36 & 14.5 \\
\hline
\end{tabular}

Table 3. Cross table of Barthel index and LDL level in Dr. Soetomo General Hospital Ischemic Stroke Patients

\begin{tabular}{ccccccc}
\hline $\begin{array}{c}\text { Admitted } \\
\text { Barthel } \\
\text { Index }\end{array}$ & $\begin{array}{c}\text { Opti- } \\
\text { mal }\end{array}$ & $\begin{array}{c}\text { Near } \\
\text { Optimal }\end{array}$ & $\begin{array}{c}\text { Bor- } \\
\text { derline } \\
\text { High }\end{array}$ & High & $\begin{array}{c}\text { Very } \\
\text { High }\end{array}$ & \\
\hline Total & 5 & 6 & 6 & 2 & 1 & 20 \\
Severe & 5 & 3 & 4 & 0 & 0 & 12 \\
\hline Moderate & 3 & 3 & 5 & 1 & 0 & 12 \\
\hline Slight & 1 & 2 & 0 & 1 & 1 & 5 \\
\hline $\begin{array}{c}\text { Indepen- } \\
\text { dent }\end{array}$ & 0 & 0 & 0 & 0 & 0 & 0 \\
Total & 14 & 14 & 15 & 4 & 2 & 49 \\
\hline
\end{tabular}




\section{Discussion}

From result, male was dominant as stated in previous study that ischemic stroke is more common in men rather than women because men tend to smoke more often than women. ${ }^{13}$ Other than smoke habit, estrogen level which is higher in women also become a protective agent for blood vessels. Estrogen treatments have been researched for women who has already in menopause. The theory is still in controversy due to possible side effects of exogenic estrogen, but it is proven that estrogen level is associated with reduction of peripheral vascular resistance. ${ }^{14}$

In this study, patients with desirable total cholesterol $(60.9 \%)$ were more than both the borderline high and high combined $(39.1 \%)$. A study also found the same result as prior research. ${ }^{15}$ Triglycerides level in this study is normal in more than half of the patients $(66.1 \%)$. Other study also found that more than half of the subjects are having normal triglycerides. ${ }^{16}$ According to AHA journal, triglycerides and total cholesterol level aren't independent risk for ischemic stroke, however there was a suggestion of increased risk for patients with high triglycerides and total cholesterol level. ${ }^{17}$ High HDL in blood is considered good. ${ }^{18} \mathrm{HDL}$ is commonly considered as "good" lipoprotein for its role in carried cholesterol to the liver so that it could be flushed out from the body and lowering risk of atherogenesis process. ${ }^{11}$ In this study, it is found that patients with low HDL level $(59.7 \%)$ is more than patients with high HDL level.

The results of this study are $71.9 \%$ of the patients have their LDL level elevated. Previous study in 2017 also found the same result. ${ }^{19}$ On the other hand, a study by Siddeswari in India found different result, which was patients with elevated LDL level were only $21.6 \%{ }^{20}$ Previous studies found that unoptimized LDL has been strongly related with stroke patient's mortality, poor outcome, and disability. ${ }^{21.23}$ LDL is an atherogenic agents because of its tendency of getting built up inside the vascular endothelial and causing atherosclerosis, narrow the vascular and causing stroke.1, 10, ${ }^{11}$ The high level of LDL in most of the patients in this study describes the indirect effect of high LDL as a risk factor of ischemic stroke. Patients with total dependency and not optimized LDL level were $75 \%$, and patients with severe dependency and not optimized LDL level were 58.3\%. This shows high level of LDL will most likely to have worse outcome. This study has several limitations such as that the use of statin or other dyslipidemia treatments are not being recorded in this study. Further study considering the treatment for dyslipidemia is considered for follow up also study regarding the effect of dyslipidemia drugs on stroke patients' outcome.

\section{Conclusion}

This study concluded that most subjects have high LDL level which might affect their functional outcome when discharge out of the hospital. This study also finds more than half of all patients have low HDL level.

\section{Conflict of Interest}

The author stated there is no conflict of interest

\section{References}

1. Indonesia, B.P.d.P.K.K.K.R., Riset Kesehatan Dasar (RISKESDAS) 2013. 2013.

2. Feigin, V.L., B. Norrving, and G.A. Mensah, Global Burden of Stroke. Circ Res, 2017. 120(3): p. 439-448.

3. About Stroke. 2018 [cited 2018 7th August]; Available from: https:// www.cdc.gov/stroke/about.htm.

4. McCance, K. and S. Hueter, Pathophysiology: the Biologic Basis for Disease in Adults and Children. Seventh Ed ed. 2014, St. Louis, Missouri: ELSEVIER.

5. Sacco, R.L., et al., An Updated Definition of Stroke for the $21^{\text {st }}$ Century: a Statement for Healthcare Professionals from the American Heart Association/American Stroke Association. Stroke, 2013. 44(7): p. 2064-89.

6. Reprint: 2013 ACC/AHA Guideline on the Assessment of Cardiovascular Risk. J Am Pharm Assoc (2003), 2013: p. e4.

7. Fahimfar, N., et al., Risk Factors for Ischemic Stroke; Results from 9 Years of Follow up in a Population Based Cohort of Iran. BMC Neurol, 2012. 12: p. 117

8. Kass, J. and E.M. Mizrahi, Neurology Secrets: Sixth Edition. 2016. $1-531$.

9. Tuomilehto, J., M. Mähönen, and C. Sarti, Basic epidemiology of stroke and risk assessment, in Textbook of Stroke Medicine, M. Brainin and W.-D. Heiss, Editors. 2009, Cambridge University Press: Cambridge. p. 77-88.

10. Mertens, A. and P. Holvoet, Oxidized LDL and HDL: Antagonists in Atherothrombosis. FASEB J, 2001. 15(12): p. 2073-84.

11. Sherwood, L., Fisiologi Manusia dari Sel ke Sistem Edisi 9. 2013, Jakarta: EGC.

12. Saposnik, G., et al., Guideline-directed Low Density Lipoprotein Management in High Risk Patients with Ischemic Stroke: Findings from Get with the Guidelines-Stroke 2003 to 2012. Stroke, 2014. 45(11): p. 3343-51.

13. Appelros, P., B. Stegmayr, and A. Terent, Sex Differences in Stroke Epidemiology: a Systematic Review. Stroke, 2009. 40(4): p. 1082-90.

14. Nicholson, C.J., et al., Estrogenic Vascular Effects are Diminished by Chronological Aging. Sci Rep, 2017. 7(1): p. 12153.

15. Olamoyegun, M.A., R. Oluyombo, and S.O. Asaolu, Evaluation of Dyslipidemia, Lipid Ratios, and Atherogenic Index as Cardiovascular Risk Factors Among Semi Urban Dwellers in Nigeria. Ann Afr Med, 2016. 15(4): p. 194-199.

16. Karim, M., et al., Association of Hypertriglyceridemia with Ischemic Stroke, Study in a Tertiary Care Hospital in Bangladesh. Journal of Medicine, 2016. 17(1): p. 21-6.

17. Bowman, T.S., et al., Cholesterol and the Risk of Ischemic Stroke. Stroke, 2003. 34(12): p. 2930-4.

18. NHLBI, NCEP-ATP III Guidelines At-A-Glance Quick Desk Reference, in National Cholesterol Education Program, U.S.D.O.H.A.H. SERVICES, et al., Editors. 2001.

19. Rai, O.N. and A. Kumar, Study of Serum Lipid Profile in Stroke Patients in Northern India. 2017, 2017. 4(5): p. 4.

20. Siddeswari, R., et al., Pattern of Dyslipidemia in Ischemic Stroke. J Med Allied Sci, 2015. 5(2): p. 26-9.

21. Song, T.J., et al., Low Density Lipoprotein Particle Size Predicts a Poor Outcome in Patients with Atherothrombotic Stroke. J Clin Neurol, 2015. 11(1): p. 80-6.

22. Tsai, N.W., et al., Statin Therapy Reduces Oxidized Low Density Lipoprotein Level, a Risk Factor for Stroke Outcome. Crit Care, 2014. 18(1): p. R16.

23. Xing, Y., et al., Low Density Lipoprotein Cholesterol and the Outcome of Acute Ischemic Stroke: Results of a Large Hospital-Based Study. Eur Neurol, 2016. 76(5-6): p. 195-201. 